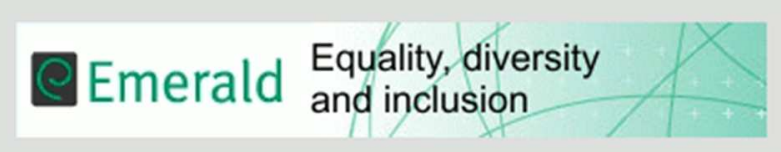

\title{
Unveiling the Myth of the Muslim Woman: A Postcolonial Critique
}

\begin{tabular}{|r|l|}
\hline Journal: & Equality, diversity and inclusion: An international journal \\
\hline Manuscript ID: & EDI-05-2012-0045.R2 \\
\hline Manuscript Type: & Original Article \\
\hline Keywords: & $\begin{array}{l}\text { Niqab, Muslim Women, Critical Discourse Analysis, Postcolonial Feminism, } \\
\text { Quebec }\end{array}$ \\
\hline \multicolumn{2}{|c}{} \\
\hline
\end{tabular}

SCHOLARONE

Manuscripts 


\section{"UNVEILING" THE MYTH OF THE MUSLIM WOMAN: A POSTCOLONIAL CRITIQUE}

\section{Introduction}

In early 2010 in the Province of Quebec, Naema Ahmed, an Egyptian-born pharmacist, was twice expelled from French language instruction classes for refusing to show her face in front of her male instructor. The Quebec government fully supported the expulsions and in March, 2010, tabled Bill 94 (Choudhury, 2012). The proposed bill requires that the face be visible during a person's interaction with government employees including education, health, social services and daycare. In essence, the Bill targets women wearing the niqab (religious face veil) who are employed by the government or are seeking governmental service (Quebec, 2010; Choudhury, 2012). As debates related to Bill 94 continue, concerns are expressed about the impact of the ban on Muslim women's access to civic participation and public service. A MacLean's magazine article suggests that the scope of the proposed law is disproportionate to the number of niqab wearers estimated between 24-90 in all of Quebec (Patriquin \& Gillis, 2010). Thus the small numbers do not explain the attention being paid to niqab-wearing Muslim women.

Throughout history women have been the chief source for influencing Islamic societies in order to alter their values (Haddad, 2007, Wallach Scott, 2007; Grace, 2004). In a sense, women are viewed as a community's most valuable possession for transmitting values to the next generation (Grace, 2004). These themes resonate today as Quebec and other Western countries such as France, Belgium and Holland place focus on the niqab and the Muslim woman. The sheer scope of concern with the niqab across various Western societies suggests, as we shall show, fundamental angst deeply rooted in neocolonial discourses.

\section{The Context of Muslims in Quebec}

Throughout Quebec's history, there has been a constant "push and pull” between the notion of plurality and protecting the French language culture, a key element of Quebec identity (Choudhury, 2012). In 1975, Quebec's Charter of Human Rights and Freedoms recognized the right of ethnic minorities to maintain their cultural life within their communities (Government of Quebec, 2011). In 


\section{"UNVEILING" THE MYTH OF THE MUSLIM WOMAN: A POSTCOLONIAL CRITIQUE}

1977, the Parti Quebecois Provincial Government passed Bill 101, also known as the Charter of French

Language, defining French as the only official language of the province (Bouchard \& Taylor, 2008).

According to Bouchard and Taylor, Quebec's government has stayed away from the Canadian

multicultural model and "respect for diversity was subordinate to the need to perpetuate the French

language culture" (p. 117).

In 1990, a moral contract was proposed in the province which centred on three aspects: a) French

as the common language for public life; b) democracy and participation; and c) pluralism and

intercommunity exchange. During this decade, the Parti Quebeqois (PQ) failed in its attempt at a

referendum on "sovereignty-association," that would see Quebec gaining political independence from

Canada while maintaining economic ties. The PQ's objective was to ensure each individual is considered

a citizen of the Province first rather than a member of their ethnic community (Bouchard \& Taylor, 2008).

Today, Quebec is recognized as `a distinct society' within a united Canada with fundamental values of

equality for men and women, separation of church and state, and primacy of the French language.

Quebec maintains its own selection criteria for immigration specifically targetting francophone

countries, resulting in more Muslim immigration numbers than experienced in the rest of Canada

(McAndrew, 2010). Over the last ten years, seventy percent of all Muslims to Canada came to Quebec

(McAndrew, 2010). As Quebec's population continues to become more multicultural, various

controversies have sparked heated debates about the niqab and Muslim woman. The niqab is filled with

deep meanings and at the centre of an assumed clash between "Islam" and "the West" (Wallach Scott,

2007, Adib-Moghaddam, 2011). As some European countries and the Province of Quebec push towards

assimilation, widespread movements of this kind have serious implications for civic engagement and

employment equity, creating potentially new boundaries to Muslim women's ability to participate, let

alone play a role, in organizational life.

In this paper, we use a postcolonial feminist lens (Mohanty, 1998, Spivak, 1987, Dube 2002) to

trace -through print and digital media - the discursive character of contemporary hostility towards the 


\section{"UNVEILING" THE MYTH OF THE MUSLIM WOMAN: A POSTCOLONIAL CRITIQUE}

niqab-wearing Muslim women. Previous research shows Orientalist (see later section on Orientalism) and colonial discourses are evident in popular press (Prasad, 1997; Prasad \& Mills, 1997; Bullock, 2007; Khiabany \& Williamson, 2008; Dye, 2011). The voices of the "other," the Muslim women, are less evident (Golnaraghi \& Dye, 2012) and thus we seek to identify and tease out these voices in order to better understand anti-colonial resistance. The discussion suggests that government and organizational policies and initiatives should recognize the diversity of Muslim women's backgrounds and encourage a fusion of cultural ideas.

We have selected two Quebec-based newspapers (the Gazette and Sherbrooke Record) representing the region in which the debates are centred. We also selected two Canadian dailies, the Globe \& Mail and National Post. The four newspapers have been chosen for their large circulation and publication frequency as well as coverage in the English language. We conducted a search on "niqab," “veil," "Muslim women" and "Quebec." We added the search term "Bill 94" for the 2010 search period. From the search results, we selected 217 articles (including 28 op-ed pieces) that dealt with Muslim women and the veil or niqab. Specifically, we selected 39 articles from The Globe \& Mail, 45 from National Post, 122 from The Gazette, and 11 from The Sherbrooke Record.

Using critical discourse analysis (CDA) (Phillips \& Hardy, 2002) of media articles, we focused on public discourse around the niqab and Muslim women in Canada, setting out to demonstrate the persistence of neo-colonial dynamics and mindsets influencing how issues regarding minority groups are evaluated today. We examined stories that dealt with the use of the niqab and the veil to construct images of the female other and gendered relationships between Western/Muslim and secular/religious women. We also attempt to look at linkages between texts and implications for employment equity in Quebec. Building on the postcolonial argument about the importance of context in the social construction of identity (e.g., forms of hybridity and postcoloniality - Amoko, 2006), we reviewed documents and texts across three different contexts -- the three periods which have sparked the most turmoil related to the niqab and the veil in Quebec's history -- namely 1994-1995, 2006-2008, and 2010. For our analysis, we 


\section{"UNVEILING" THE MYTH OF THE MUSLIM WOMAN: A POSTCOLONIAL CRITIQUE}

also selected the Bouchard and Taylor official report commissioned by the Province of Quebec in 2007 given the report's centrality to the debates between the 2006-2008 period.

\section{The Postcolonial Feminism Lens}

"The feminist tradition has made significant contributions to a wide range of disciplines, including organizational and management studies" (Prasad, 2005, p. 181). In fact, feminism has much in common with postcolonialism as both traditions explore the struggle against oppression, injustice and objectification. Postcolonial theory radically critiques colonialism, imperialism and neo-colonialism (Banerjee \& Prasad, 2008) and can help unveil neo-colonial assumptions that underpin cross cultural management and contemporary social arrangements. Postcolonial theory posits that Western colonialism is a significant aspect of social life given its geographical reach of approximately $85 \%$ of the world in the early to mid-Twentieth century (Said, 1978) and to this day influences western notions of gender dynamics (Spivak, 1987). In essence, postcolonial theory attempts to "critique and analyze the complex and multifaceted dynamics of modern Western colonialism" (Bannerjee \& Prasad, 2008, p. 91) and the “ongoing significance of the colonial encounter for people's lives both in the West and the non-West" (Prasad, 2003, p. 5). While postcolonial theory critiques obvious aspects of Western colonization, it also focuses on the more subtle dimensions of culture, imperialism and discourse (Prasad, 1997).

Postcolonial theory gained importance with Edward Said's Orientalism (1978), an influential study of discursive aspects of colonialism and ideologies with respect to the Middle East and Islam (Prasad, 2006). This Western discourse created a reality in which certain peoples were constructed as objects of control and portrayed as being fit only for conquest, subjugation and colonization (Prasad, 1997). Constructs such as the "Orient," the "Third World," and "Third World women" are western inventions based on fictitious assumptions that ontologically and epistemologically are polar opposite to the Occident, the West and Western Women (Said, 1978). While the Occident or West is associated with privileged discourse such as developed, superior, and modern, the Orient or non-West is ontologically inferior, backward, and archaic (Said, 1978; Prasad, 2006) and thus in need of supervision and guidance 


\section{"UNVEILING" THE MYTH OF THE MUSLIM WOMAN: A POSTCOLONIAL CRITIQUE}

to become civilized and modern. Therefore, the discourse of colonization is anchored in the construction of an ontological non-Western "other," and at the same time helping define the West as a contrasting image (Said, 1978). Postcolonial theory is therefore useful in the analysis of the continuing scope of colonialism that shapes Western perceptions of the "other" (e.g., the niqab wearing Muslim women) which are prevalent to this day (Prasad, 2005).

Postcolonial feminism resulted from a reaction against the lack of attention to gender issues in mainstream postcolonialism and Western feminism's tendency to define gender and women as a single and universal construct (Dube, 2002; Calas \& Smircich 1996). Mohanty (1988) has questioned the construction of the "third-world woman" as a homogeneous category in western feminist texts arguing against a singular assumption that all western and non-western women have identical interests. Western feminist scholars tend to portray Islam as a patriarchal religion with little scope for gender equality for women (Syed, 2010). Syed (2010) goes onto argue that the "mainstream feminist tendency is to view Islam and gender discrimination as intertwined (p. 151). Mohanty (1987) argues that the "third-world woman" is produced in Western feminist texts as "sexually constrained" and "ignorant, poor, uneducated, tradition bound, religious, domesticated, family-oriented, victimized" (p. 65). This is in contrast to the construction of the western woman as "educated, modern, as having control over their own bodies and sexualities, and the freedom to make their own decisions" (p. 65). Gayatri Chakravorty Spivak, an influential contributor to postcolonial feminist theory, is critical of many western feminists and their sense of privilege that propels them to save their Third world counterparts (Spivak, 1987). Spivak also references the subaltern, non-elite colonial subject, and the "doubly marginal figure ... under conditions of neo-colonial domination" (Prasad, 1997, p. 24). Mohanty and Spivak point to a cross-cultural concern about women and agree that postcolonial feminism is a complex space and are sceptical of the western feminist claim that their interests are fully in common with those of all women. Postcolonial analyses "often focus on the complex subjectivities produced by intersections of gender, race, class, ethnicity, etc. in the context of specific First World/Third World relationships" (Calas \& Smircich, 1996). 


\section{"UNVEILING" THE MYTH OF THE MUSLIM WOMAN: A POSTCOLONIAL CRITIQUE}

The niqab, the veil and Postcoloniality

In this paper, we adopt a postcolonial feminist lens in an effort to offer an explanation for Quebec's Bill 94 and the resulting debates. In particular we focus on postcoloniality as an influence on the debates (i.e., understandings of the 'other' as a result of interactions between people who formerly stood in different colonial relationships) (Amoko, 2006). Through CDA (Phillips \& Hardy, 2002) of selected texts, we seek to understand the extent to which postcoloniality informs the debate around the curtailment of the niqab and what the implications are for the social identities of those who stand in different relations to the debate. Of particular interest is the impact of this debate on the growing number of Muslim immigrants to Canada (predicted to grow from 2.4 to over 7 per cent of Canada's population over the next 20 years - Lewis, 2011), and their relationships with their adopted homeland.

CDA is primarily interested in and motivated by pressing social issues, aiming to understand, describe and explain how power, injustice and inequality are enacted through discourse (Van Dijk, 1993). It emphasizes unequal power relations and ideologies created by and represented in language (EasterbySmith, Thorpe, \& Jackson, 2008). Discourse is "an interrelated set of texts and the practices of their production, dissemination, and reception, that brings an object into being” (Phillips \& Hardy, 2002, p. 3). In this case, the objects that we are interested in are "gender," "Third World Women," and the "niqab." CDA focuses on how discursive activity privileges some actors at the expense of the marginalized “others" (Phillips \& Hardy, 2002). Given the influence of Foucault's discourse analysis on Said's (1979, 1993) development of postcolonial theory, we view CDA is a valuable method for postcolonial feminist research, enabling examination of texts to see the subtle (and not so subtle) ways in which assumptions related to gender and the Third World women are discursively produced, sustained, negotiated, and challenged (Lazar, 2007).

A critical approach requires constant introspection by the researchers suggesting that we constantly examine and surface our own situated positions. We are western researchers, who live in Canada (outside the Province of Quebec). Therefore, our interpretations of events are mediated through 


\section{"UNVEILING" THE MYTH OF THE MUSLIM WOMAN: A POSTCOLONIAL CRITIQUE}

our own situatedness and the reader needs to take into account the extent to which we are able to capture the experiences of reflecting on power elites, hierarchy of power, and hegemony in our analysis of hostility towards the niqab-wearing Muslim women (Van Dijik, 1993, p. 252), while attempting to give the Muslim women a voice. We also know that the texts we have chosen to privilege are generated by Western institutions and commentators such as journalists, and so on. To tease out the voices of the niqab-wearing Muslim women, in addition to media articles, we have drawn from official statements in response to Bill 94 from various groups such as the Canadian Council of Muslim Women (CCMW, 2010), and the 'No to Bill 94 Coalition.' .

\section{Discourses in Documents and Texts}

The Veil Controversy-1994-1995

The first article in 1994 detailing a controversy related to the veil was published in The Gazette regarding a judge who expelled a Muslim woman for wearing a head scarf in court. Along side this event were others that same year that made the headlines, including two Muslim girls who were told they could not attend their respective public Catholic schools without removing their head coverings. These events sparked media attention of the covered Muslim women in the newspapers.

Two prominent discourses are apparent in the papers between 1994-1995. The most dominant discourse involves Muslim women's agency and the veil. Secular and religious Mulsim women dominated the pages arguing for their choices to be respected. The Canadian Charter of Rights and Freedoms is mentioned several times as protecting these women's rights. Further, interpretations of the Quran are cited with the dominant views positioning the veil as a source of empowerment, as well as a sign of modesty and acceptance of faith. Western female perspectives about the oppressive character of the veil surfaced but to a smaller extent during this period.

Discourse constructing Islam and the Muslim women as the "other" emerge from symbolic icons of Quebec society. Francois Lemieux, President of Montreal's St. Jean Baptiste Society (SJBS), makes several controvertial remarks throughout this period about the veil including "wearing the hijab is not 


\section{“UNVEILING” THE MYTH OF THE MUSLIM WOMAN: A POSTCOLONIAL CRITIQUE}

compatible with our project,"(Norris, 1994, para. 2) “wearing a hijab defies the values of the equality of men and women that we have here in Quebec," (Norris, 1994, para. 6) and "wearing the hijab is related to the part (of Islam) where poligamy exists. It is seen for sexual exploitation of women" (Nasrulla, 1994, para. 21). During this period, Lemieux was closely aligned with the PQ and the fight for an independent Quebec (Agen, 1999). Lemieux's bold statements sparked a multitude of Muslim women's voices to emerge in opposition. These women argue for freedom of choice and religion.

In 1994, the PQ won the Quebec provincial election and part of their mandate was to hold a referendum on Quebec's sovereignty from Canada in 1995. During this time, the Roman Catholic Church, the SJBS, the PQ, the Montreal Catholic School Commission were set in opposition in various articles against Muslim women, Muslims and Islamic fundamentalists. Ensuing debates framed each side as fundamentalists in their own way wanting to divide society for their own purposes. For example, one particlar article titled "Montreal Muslim headgear polarizes Quebec" (Mackie, 1994) cites polarization in Quebec as creating an 'us and them' environment. The growing discourse depicted the veil and covered Muslim women as symbols of terrorism and fanaticism. In their analysis of hyperveiling in France, Lewis \& MacMaster (1998) argue that "veiling and concealment are [seen as] inherently sinister, ... and lurking always behind the figure of the woman is the shadowy fundamentalist, the fanatical bomber who manipulates her" (para. 25). Francophone Quebecers, on the other hand, are framed as being intolerant of multiculturalism and following France's move to ban the hijab in schools in this same year. A comment from Sarah Khan, a Muslim woman who chooses to wear the veil, asserted that minorities do not fit into what the SJBS and PQ are looking for and that they will be completely unwelcomed in a future independent Quebec. The PQ lost the 1995 referendum by a slight margin and Jacques Parizeau, then PQ leader, attributed the defeat to "money and the ethnic vote" suggesting rich anglo Montrealers and the ethnic minority were responsible for the loss (CBC Digital Archives, 1995).

During this period, the image of the veiled Muslim woman is one who has agentic capabilities, able to resist Western hegemony. Muslim women's voices are heard loudly fighting for their rights and 


\section{"UNVEILING" THE MYTH OF THE MUSLIM WOMAN: A POSTCOLONIAL CRITIQUE}

freedom. For example, this is exemplified in a notable quote from Homa Hoodfar an Iranian-born anthropology professor teaching in Quebec who said "if anything the hijab permits women from being seen only as hips and breasts. In a society that projects images of women as all hips and breasts and no intelligence, it is a way of saying I'm not just hips and breasts - I'm an intelligent person" (Norris, 1994). The Reasonable Accommodation Controversy-2007-2008

Between June 2006 to March 2007, 40 accommodation cases (i.e. attempts to embrace different religions in mainstream culture) were reported in newspapers compared to 13 between December 1985April 2002 and 12 cases between May 2002 and February 2006 (Bouchard \& Taylor, 2008). The papers covered a range of stories touching three religious groups: Muslims, Jews and Sikhs. Controversies reported varied with the most prominent included the renaming of the Christmas tree in City Hall to "the Tree of Life," the YMCA replacing the exercise room windows with frosted glass at request of Orthodox Jewish congregation, hijab bans in schools and sports tournaments, and Sugarhouses accommodating Muslims with pork-free pea soup and prayers in the dance hall.

The outpouring of accommodation stories in the media was accompanied by a dominant crisis and discourse of anxiety within Quebec - a population reacting to accommodation requests as though it felt wronged by what was perceived to as an attack on Quebec's core values. The language of the ensuing debates pointed to Muslims overrunning Quebec - in essence, a fear that Islam would colonize Quebec. Muslims became a symbol for a clash of cultures (Wallach Scott, 2007; Adib-Moghaddam, 2001), with Muslim women in particular being seen as characterizing Muslims inability or unwillingness to assimilate to Quebec culture and vales.

Several events covered in the media in early 2007 point to this shift in discourse. A Leger Marketing survey released results indicating that $59 \%$ of Quebecers admiting to being racist to some degree and that 50\% have a bad opinion of Muslims (Bouchard \& Taylor, 2008). Another story received significant coverage about Herouxville, a small rural Quebec town, that passed its own code of conduct for new Canadians (Martin, 2007), including prohibitions on supposed normal Muslim practices of 


\section{"UNVEILING" THE MYTH OF THE MUSLIM WOMAN: A POSTCOLONIAL CRITIQUE}

"killing women by stoning or burning women alive in public places, burning them with acid ... or treating them as slaves" (Hamilton, 2007, para. 17). The code also stressed that (supposedly in contrast to other cultural values) "a woman can ... drive a car, vote freely, sign cheques, decide for herself, speak her peace, dress as she sees fit [in addition to a range of other activities]" (para. 16).

This early period also leads up to the Provincial elections in March 2007 with all three political parties placing focus on multiculturalism, secularism and cultural and religious accommodation. The discourse of immigrants and Muslims as the "other" once again surface. The Action democratique du Quebec (ADQ) camp, a conservative, nationalist party released an open letter denouncing other political leaders for their submission to "the old reflex of the minority" that encourages Quebecers to "give in" and "collectively fade in the background" when the time comes to assert their values (Bouchard \& Taylor, 2008). A number of articles dealt with Mario Dumont's (ADQ leader) exploitation of this issue in order to play off voter emotions in his rural Quebec riding.

He is described as 'fanning the embers of intolerance. Immigrants are 'les autres.' They have to bend to Quebec's customs, not the other way around" (Bagnall, 2007, para. 10). During the same time, a discourse of moderation and tolerance in favour of immigrants emerges from the Liberal party's Premier Jean Charet. Charet established the Consultation Commission on Accommodation Practices related to Cultural Differences in February 2007 to look at accommodation issues in Quebec - a month before the elections (Bouchard-Taylor Commission),

From the onset of the Summer of 2007, the papers began to cover the Bouchard-Taylor Commission's investigations and hearings. The predominant discourse until October 2007 reflected themes of Quebec's identity at risk, fear of Muslim immigrants, and francophone concern for the fragility of the French language. The connotation was that Quebecers are colonized [by Muslims] and in danger of extinction. A ping pong debate primarily framed around the veil, niqab and the Muslim community began to dominate the pages through the latter half of the year. Examples include: 


\section{"UNVEILING" THE MYTH OF THE MUSLIM WOMAN: A POSTCOLONIAL CRITIQUE}

- A Montreal firefighter objected that his son can't wear his baseball cap in high school even through hijabs are allowed (Heinrich, 2007, para. 8)

- "Teachers and daycare workers in hijab are a threat, because children trust the people looking after them, and is practically a kind of subversion. I don't want Muslim parents transmitting their religion to my children" (Heinrich, 2007, para.6)

- An Algerian woman says "Is this the Quebec I chose? Not all immigrants come from Afghanistan and Herouxville is not Quebec" (Heinrich, 2007, para. 12)

- A woman wearing the hijab tells the commission that she is not a terrorist or a religious extremist. She chooses to wear the hijab against the wishes of her parents and calls it a sign of modesty (Hamilton, 2007, para. 13)

By the end of 2007, it would appear that the pendulum of opinion had swung to a discourse of fear from Muslim immigrants. For example, several Muslims warned immigrants to think twice about coming to Quebec. Within the Bouchard-Taylor Commission's' investigation the discourse of agency by the Muslim community comes to light, although more subtle in tone. An article quoted Muslims who identify themselves as the "silent majority of moderate Muslims" (Heinrich, 2007, para. 16) who do not need special accommodation, but instead wish for acceptance, as well as fair and equal treatment. This discourse is markedly different to earlier reportings where Muslims were depicted as assaulting Quebec values.

The release of the Bouchard-Taylor Commission's final report in 2008 marked a discourse of tolerance and harmony with notions of an "open secularism (laicite overte) model," "harmonization," and "tolerance for the veil and niqab" being touted. Voices from the Canadian Islamic Congress and Muslim Council of Canada supported the report for its avoidance of sensationalism and exaggerations, in hopes that Quebec can now live in peace.

Unlike 1994, government officials began to take a particular interest in what should count as reasonable accommodation from the March 2007 election onward, particularly focusing on Muslim 


\section{“UNVEILING" THE MYTH OF THE MUSLIM WOMAN: A POSTCOLONIAL CRITIQUE}

women. With two provincial elections during this period (2007 and 2008) and a federal election (2010), there developed a public debate, ostensibly about the avoidance of polling irregularities, that focussed on niqab-wearing Muslim woman as exemplars of the problems faced by a democratic, multi-cultural society' asking 'can you be allowed to vote while hiding your face?' (Ha, Peritz, \& Marotte, 2007). A handful of Muslim voices surfaced in resistance, claiming that the ensuing controversy was being fueled by Islamophobia by giving non-Muslim Canadians the wrong impression about Muslims. These voices also pointed out that there had never been a request made by Muslims for accommodation at polling stations. For example, Shama Naz, a niqab-wearing Muslim woman said "the issue has been blown out of proportion ... Muslim women routinely remove their face veils for security matters ... if election officials had spoken to me they would have known I wouldn't mind identifying myself at the ballot box" (Ha, Peritz, \& Marotte, 2007, para. 17).

In examining public discourses during this period, we also noted the gendered character of much of the debate, evoking and privileging masculinities on both sides of the argument. The notion of "the system of hierarchical binaries" (Prasad, 1997) (i.e. modern/traditional, Quebecer/Muslim, secular/religious etc.) is more prominent during this time. Discourses at the start of the period, portray Muslims as a powerful threat to Quebec and Quebec in the weaker position. Towards the end of 2007, this discourse mutates, linking secular Quebec to a superior position while at the same time portraying the Muslim woman and Muslim community as a powerful threat to Quebec's identity. This discourse was likely further aggravated in Quebec due to large scale immigration beginning in 2002 onward, attracting a larger percentage of immigrants from North Africa and the Middle East. While migration brings different nations and cultures closer together, differences may become more pronounced and problematic (Prasad \& Prasad, 2002). During this period, the paradox of "compression" and "implosion" become apparent in Quebec (Prasad \& Prasad quoting Freedman, 2002). On one hand, migration reduces physical space between different cultures (compression). On the other hand, it is also resulting in increased awareness and consciousness of one's own culture and national identity as seen to be the case in Quebec 


\section{"UNVEILING" THE MYTH OF THE MUSLIM WOMAN: A POSTCOLONIAL CRITIQUE}

(implosion). Thus, these migration patterns place strains on the systems of binaries, resulting in activities and policies aimed at safeguarding the binaries (Prasad, 2006).

Another development seemingly placing further complexity in the debates is the increasing 'white backlash' (Prasad \& Mills, 1997; Prasad, 1997). 'White rage' and the polarization of cultural differences (Prasad \& Mills, 1997) can be an outcome of compression in constituencies such as Quebec. Prasad and Mills suggest that white rage has manifested in the United States in the assault on affirmative action, tougher immigration laws in California and claims of superior intelligence by certain racial groups. In Quebec, we see the beginnings of a similar manifestation related to Muslims. By the end of 2008, several articles highlight Immigration Minister, Yolanda James assertion that future immigrants to Quebec will be required to sign a declaration promising to learn French and respect Quebec's 'shared values.' Minister James was quoted as saying "coming to Quebec is not a right, it is a privilege. If you refuse to sign the declaration you won't be able to come here" (Gazette, 2007, para. 5).

During this period we see a growing trend in Quebec displaying antagonism towards cultural and religious minorities - predominantly Muslim women and communities. The post 9/11 environment and the notion of Islamophobia followed by a flury of accommodation cases feuled in the media served to create a climate of crisis. Thus Islam is portrayed more pronouncedly as the "other" culture and dominated by issues of "security, terrorism and the question of Western identity versus Islamic identity" (Schumann, 2007; Bullock, 2007; Choudhury, 2012).

The Gender Equality Crisis - 2010

This period marks another significant mutation in dominant discourses related to the Muslim women. In early 2010, another accommodation case hit the media although this time with a different tone. The niqab-wearing Muslim woman is portrayed as being difficult, resistant, and an aggressor. Khiabany and Williamson's (2008) analysis of the British controversy regarding the niqab also found that media representation of veiled women was that of aggressor who has been given too much freedom and agency by Western Liberalism. Headlines covering the Quebec incident include "Niqab interferes with 


\section{"UNVEILING" THE MYTH OF THE MUSLIM WOMAN: A POSTCOLONIAL CRITIQUE}

language teaching: Quebec; Woman Expelled" (Scott, 2010) and "Niqab heats up rights controversy; Row over veil; Woman refused to uncover face in French class" (Scott, 2010).

Discourses of gender equality are dominant where the government is "drawing a line" (Galloway \& Taber, 2010, para. 5) “protecting Quebec values”(Galloway \& Taber, 2010, para. 5) and "principles of gender equality" (Hamilton, 2010, para. 2). The gender equality discourses may be fuelled by postSeptember 11 Islamophobia, as well as the media's amplification of the treatment of Muslim women by the Taliban in Afghanistan, by the Islamic Government of Iran, and by Muslim men right here in Canada. Lewis \& MacMaster (1998) argue that Western media typically portray veiled women "as carrying weapons, establishing an equation between the oppression of women, fanaticism, and terrorism ... the veil is the signifier ... of an entire social, political, and cultural order (barbarism, oppression, medieval values, fanaticism)" (para. 22). Stories related to honour killings receive significant media and public attention. The veiled woman is seen as the symbol and victim of patriarchal oppression and seclusion (Lewis \& MacMaster, 1998). While the discourse surrounding the privileging of Western values of secularity and equality existed in previous periods, the focus on gender equality, as the discourse of patriarchy and cultural (viz. Western) hegemony become strongly entrenched with the introduction of Bill 94 in March 2010. Premier Jean Charest said in a prepared statement "The Quebec nation has values, solid values ... these values are fundamental. They cannot be the the object of any accommodation. They cannot be subordinated to any other principle" (Elmasry, 2007, para. 13). As evident from this quote, the cultural values of the Quebec Nation and Muslims is "made as wide as possible so as to suggest the impossiblity of integration and to maximize dangers presented to [national] values and unity" (Lewis \& MacMaster, 1998, para. 25).

This hardening is further evidenced by the Federal government's support for the ban as well as an Angus Reid Poll in 2010, suggesting that $95 \%$ of Quebecers and 75\% of Canadians in the other provinces supported the proposed provincial law barring the niqab from government offices, schools, and other publicly funded institutions (Scott, 2010). Around the same period, a Leger Marketing poll indicated that 


\section{"UNVEILING" THE MYTH OF THE MUSLIM WOMAN: A POSTCOLONIAL CRITIQUE}

approximately 50\% of English Canadians didn't feel Muslims share their values, and 74\% of French speaking respondents sharing the same sentiments (Thompson, 2010).

We found it interesting that the media outlets we selected disproportionately gave space to government officials and secular Muslims in favour of the niqab ban with very little privileging of voices in opposition. Here we are reminded of Spivak's (1987) notion of the subaltern woman, more deeply shadowed and muted by the dominant ideology. Throughout this period, the discourse also plays on secular Muslim elites or "cultural insiders" (Bilge, 2010) such as the Muslim Canadian Congress (MCC), serving to further validate the Western paradigm of Islamic inferiority. These "cultural insiders" function as "good Muslims" who are unveiled, enlightened and secular, playing to the Western stereotypes (Bilge, 2010). This discourse informed by postcolonial attitudes is constructed as bringing "progress," "liberation," and "modernity" in the western sense, to the "oppressed," "helpless," "powerless" niqabwearing Muslim woman. The oppression of Muslim women appears to be a discursive tool seeking to justify government intervention via the proposed ban. Central to this discourse is the equation of the niqab with women's oppression, thus denying agency of these women (Bullock, 2007). For example, government officials such as Christine St-Pierre, the Quebec Minister responsible for the status of women,- are cited as referring to the niqab as "ambulatory prisons," "an attack on women's rights" and “unacceptable in our society” (Patriquin \& Gillis, 2010).

The hegemonic (paternalistic) discourse becomes even more evident in the symbolic images portrayed by the texts of Government officials, feminist organizations such as the Federation des femmes du Quebec (FFQ, 2010), and "cultural insiders" such as MCC as the saviours to these marginalized women. The gendered discourses that stem from binary divisions serve to position the Western elite in opposition to the Muslim women - in essence demonstrating the privileged role of Western feminists, the Quebecers, the secular, the modern as masculine, and the traditional, Muslim, religious woman as feminine. "The plight of the veiled woman still largely remains determined within and by masculinist 


\section{"UNVEILING" THE MYTH OF THE MUSLIM WOMAN: A POSTCOLONIAL CRITIQUE}

discourse, confirming that female history is always 'disfigured', confined to the shadows of colonial and phallocentric representation" (Grace, 2004, p. 211).

The discourse related to the construction of the niqab-wearing Muslim woman is "homogenizing," lumping all Muslim women into one generalized group with the assumption of a common and universal campaign against patriarchy. This discourse points to the danger noted by Mohanty (1998) that homogenization based on Western values reinforces Western cultural imperialism (Dube, 2002). Further, to assume that the practice of wearing the niqab or veil by women "in a number of Muslim countries indicates the universal oppression of women ... is not only analytically reductive, but also proves to be quite useless when it comes to the elaboration of oppositional political strategy“" (Mohanty, 1998, p. 63).

In the previous two periods (1994 and 2007), voices of Muslim women and advocacy organizations were more dominant in the media selected than in the 2010 period. A search of other Canadian dailies (mostly suburban), blogs and feminist and Muslim women's organization websites surfaced discourses by Muslim and secular women's organizations resisting Bill 94. The discourses of resistance served to "decolonize" Western notions of gender and equality. New and stronger tensions have emerged during this debate at the intersection of race and gender. These discourses argue for a "pluristic" notion, depending on the context in which the act of wearing a head or face cover is carried out and how and where women see dominance. We are reminded of Mohanty's (1998) emphasis on recognizing "the need for Third-world women to define their own realities from their own perspectives and that the authority of their own discourses should be accepted" (Dube, 2002, p. 105).

These resistant voices also struck back at the dominant discourse by arguing that by forcing women to remove their niqab, Quebec was no different from countries where women were forced to be veiled. This discourse of resistance also highlighted the Muslim women's sense of agency and choice by asserting their right to dress as they wish and interpret the Quran as they wish. As noted by Wallach Scott (2007: 37), this choice could stem from a number of different reasons including a way of demanding 


\section{"UNVEILING" THE MYTH OF THE MUSLIM WOMAN: A POSTCOLONIAL CRITIQUE}

respect for difference, a call for integration without assimilation, desire for recognition, protesting against discrimination, or empowerment through access to public space. For example, a niqab-wearing Muslim woman had this to say: “Wearing a niqab doesn't mean I'm oppressed by my husband. In fact, he is home now taking care of our nine-month old baby. Actually what upsets me the most about this issue is that I really don't have time for this. I'm trying to get into law school.” (Cole, 2010, para. 13).

\section{Discussion}

This paper sought to develop a postcolonial understanding of critical issues regarding the conditions that constitute the system in which Muslim women are required to operate in Quebec and the material impact of Bill 94 on this disadvantaged "other." Postcolonial feminist theorizing is useful in identifying how Muslim women from different countries are affected in the patriarchal systems of the West but also within their own systems (Dube, 2002). It recognizes the intersection of gender, race, ethnicity, etc. which tends to be ignored across Western feminist perspectives (Bagilhole, 2010; Holvino, 2008). Postcolonial feminism offers a powerful lens through which we can study gendered space of oppression by “investigating how Western constructions may reduce women to silence, either by replacing flexible gender systems with rigid and dualistic ones or by reinforcing non-Western patriarchal systems" (Dube, 2002, p. 115).

As forces of globalization serve to compress physical spaces, it is vital for Muslim women to assert their differences. This does not mean ignoring the oppressive aspects of a particular culture (e.g., violence against women in some western societies and honour killings in some non-western societies). Such practices should be confronted, questioned and rejected without necessarily embracing colonial discourse of discarding all aspects of one's culture (Dube, 2002). Nor does it mean embracing assimilationism (Porter, 1975). If anything globalization and migration further call for policies that encourage hybridity (i.e. a fusion of cultural ideas) and an understanding of the role of neo-colonialism in public discourse. 


\section{"UNVEILING" THE MYTH OF THE MUSLIM WOMAN: A POSTCOLONIAL CRITIQUE}

Supporters of Bill 94 have tended to draw on western feminist notions of a universal campaign against patriarchy; at times discursively but at times cynically. Postcolonial feminism is sceptical of the evocation of such common interests among women regardless of race, ethnicity, etc. (Prasad, 1997). The discourses in the construction of Muslim women have intensely mutated over time towards Western cultural hegemony and paternalism, and the Muslim woman as oppressed and in need of saving. These notions come under pressure when we look at labour market access among Muslim females. Syed (2007) findings suggest that ethnic minority women remain disadvantaged within society and organizations, and deprived of the opportunities available to mainstream women. These findings "contradict the classical feminist perspective that treats all women's issues as primarily the same" (Syed, 2007, p. 1971).

Extant literature suggests that immigrant women experiences and issues in the workplace are very different than their Western female counterparts (Syed \& Pio, 2010). One significant challenge to labour market access by immigrants is language barriers (Mills \& Prasad, 1997; Syed \& Murray, 2009). By denying access to social services such as language classes, Bill 94 serves to put Muslim women at risk of “missing various social and economic opportunities" (Choudhury, 2012, p. 15). According to Choudhury, language training allows individuals to access and more quickly integrate into the labour market. Muslim women may face additional barriers to labour market as well as discrimination due to additional complexities presented by their gender, ethnicity, religion and immigration (Syed \& Murray, 2009; Syed \& Pio, 2010). According to one immigrant, "The debate over reasonable accommodation has fanned discrimination against people from Middle Eastern backgrounds ... it fosters a climate whereby employers feel they can refuse or reject people without any serious consequences" (Scott, 2010). These trends have implications for employment equity and labor market access for the Muslim woman.

Unemployment rates for Muslim women stand at the highest level within major faith communities and the unemployment rate of 16.5 percent in 2001 was more than double the national female unemployment rate (Hamdani, 2005). Data from the 2006 Census shows despite the fact that university graduation rates among immigrant women is $24.4 \%$ (above Quebec's $16.5 \%$ ), nearly 3 out of 


\section{"UNVEILING" THE MYTH OF THE MUSLIM WOMAN: A POSTCOLONIAL CRITIQUE}

10 of these women experience deskilling (Bouchard \& Taylor, 2008). Moreover, Muslim women who wear the headscarf are generally discriminated against in the labour market (Hamdani, 2005; Bouchard \&Taylor, 2008). Developments of the proposed Bill 94 served to exacerbate barriers further. The legislation could potentially deprive affected women of their right to attend university, receive publically funded health care, and seek employment within public service. The Bill, if passed, may serve to send a dangerous signal to the private sector. Accordingly, we support Syed's (2007) proposal that government and organizational policies and initiatives recognize the diversity in Muslim women's backgrounds and recognize the dangers of privileging mainstream women's perspectives.

We recognize our account of events presents an alternative lens and partial history of events in Quebec. We also recognize that there may be other accounts of the same series of events. We accessed texts from four English speaking daily news sources and recognize the limitation of not having examined French language discourses. We attempted to attain the transcripts from the various public hearings in English, but none were available. Our aim was to privilege some of the embedded beliefs and values behind dominant official accounts of Quebec in relation to the Muslim woman and Bill 94 by looking at news reports describing unequal encounters. In the process we have attempted to destabilize the notion of gender and identity within a global context. The fate of Bill 94 still remains to be seen as public hearings come to an end.

Future scholars may wish to extend this study through examining discourses of secular, veil and niqab-wearing Muslim women; newcomers, those living in Canada for a longer period and those born in Canada; and those from different countries of origin. Another area of research that is ripe for exploration is workplace experiences of Muslim women in Canada. Additionally, examination of overt and subtle discrimination faced by Muslim women would provide important insights into employment equity and human rights. 


\section{"UNVEILING" THE MYTH OF THE MUSLIM WOMAN: A POSTCOLONIAL CRITIQUE}

\section{Bibliography}

Adib-Moghaddam, A. (2011). A Metahistory of the Class of Civilazations. London: Hurst and Company.

Agen, M. C. (1999). Politics of the Societe Saint-Jean-Baptiste de Montreal. American Review of Canadian Studies , 29 (3).

Ahmed, L. (1992). Women and Gender in Islam: Historical Roots of a Modern Debate. New Haven: Yale University Press.

Amoko, A. (2006). From Race and Postcoloniality In S. Malpas, \& P. Wake, The Routledge Companion to Critical Theory (pp. 127-140). Oxon: Routledge.

Anonymous. (2008). Values pledge 'a slippery slope'; Immigrant groups uncomfortable with Charet's plan, The Gazette, Montreal, Quebec, Canada.

Bagilhole, B. (2010). Applying the Lens of Intersectionality to UK Equal Opportunity and Diversity Policies. Canadian Journal of Administrative Science, 27(3), 263-271.

Bagnall, J. (2007, March 28). Shameful rise in intolerance for veiled voters. The Gazette, Montreal, Quebec, Canada.

Bagnall, J. (2007, February 7). There's an easy way for Herouxville to defend women's rights. The Gazette, Montreal, Quebec, Canada.

Banerjee, S., \& Prasad, A. (2008). Introduction to the special issue on Critical reflection on management and organizations: a postcolonial perspective. Critical perspectives on international business , 4 (2/3), 90-98.

Bilge, S. (2010). Beyond Subordination vs. Resistance: An Intersectional Approach to the Agency of Veiled Muslim Women. Journal of Intercultural Studies , 1, 9-28.

Bouchard, G., \& Taylor, C. (2008). Building the Future: a time for reconciliation. Government of Quebec.

Bullock, K. (2007). Rethinking Muslim Women and the Veil. International Migration \& Immigration . London, UK: International Institute of Islamic Thought.

Calas, M., \& Smircich, L. (1996). From 'The Women's' Point of View: Feminist Approaches to Organization Studies. In S. R. Clegg, C. Hardy, \& W. Nord, Handbook of organiztion studies (pp. 218-257). London: Sage Publications.

CBC Digital Archives (1995). Quebec Referendum Reaction. Retrieved October 3, 2012 from CBC: ttp://www.cbc.ca/archives/categories/politics/federal-politics/separation-anxiety-the-1995-quebecreferendum/money-and-the-ethnic-vote.html.

Choudhury, N. (2012). Niqab vs. Quebec: Negotiating Minority Rights within Quebec Identify, The University of Western Ontario Journal of Legal Studies. Retrieved September 28, 2012, from UWOJ Leg Studies Online: http://ir.lib.uwo.ca/uwojls/vol1/iss1/2/. 


\section{"UNVEILING" THE MYTH OF THE MUSLIM WOMAN: A POSTCOLONIAL CRITIQUE}

Cole, S. (2010, May 4). No/Non Bill 94 Calling out the Quebec Law to Ban Niqabs. NOW Magazine .

Dube, M. (2002). Postcoloniality, Feminist Space, and Religion. In L. Donaldson, \& K. Pui-Lan (Eds.), Postcolonialism, Feminism \& Religious Discourse (pp. 100-120). New York: Routledge.

Dye, K. (2011) Holding our Words Against Us: Cooption of the Feminist Discourse to Perpetuate Ethnic Discrimination. Presented and published in the proceedsings of the Critical Management Studies conference in Naples, Italy, July, 2012.

Easterby-Smith, M., Thorpe, R., \& Jackson, P. (2008). Management Research: Theory and Research. London: SAGE.

Elmasry, M. (2007, February 13). Defining a Quebecer will not be an easy task. The Record . Kitchener, Ontario, Canada.

Federation of Quebec Women. (2010, 24 March). Wearing religious symbols in public service: A step in the right direction according to the Federation des femmes du Québec. Retrieved August 5, 2010, from Federation des femmes du Quebec: http://www.ffq.qc.ca/2010/03/port-de-signes-religieux-dansla-fonction-publique-un-pas-dans-la-bonne-direction-selon-la-federation-des-femmes-du-quebec/

Galloway, G. \& Taber, J. (2010, March 27). Liberals, Tories back Quebec's veil ban. The Globe and Mail. Toronto, Ontario, Canada.

Golnaraghi, G. \& Dye, K. (2012). Discourses of contradiction: A postcolonial analysis of Muslim womenand the veil. Paper presented at the Academy of Management conference in Boston, MA, August, 2012 .

Government of Quebec. (2011). Portraits of Quebec. Retrieved 04 04, 2011, from Quebec: http://www.bonjourquebec.com/qc-en/histoire $0 . h t m l$

Grace, D. (2004). The Woman in the Muslin Mask: Veiling and Identity in Postcolonial Literature. Cornwall: MPG Books.

Ha, T. T., Peritz, I., \& Marotte, B. (2007, March 24). Lift face veils or don't vote, Quebec tells Muslim. The Globe \& Mail. Toronto, Ontario, Canada.

Haddad, Y. Y. (2007). The Post 9/11 Hijab as Icon. Sociology of Religion. 68(3), 253-267.

Hamdani, D. (2005, March). Documents: Triple Jeopardy. Retrieved November 11, 2010, from CCMW Website: http://www.ccmw.com/documents/Triple_Jeopardy.pdf

Hamilton, G. (2007, November 2). Debates opening wounds: At the extremes there was racism, antiSemitism. National Post. Toronto, Ontario, Canada.

Hamilton, G. (2010, March 25). Show Face, Quebec Says. National Post. Toronto, Ontario, Canada .

Heinrich, J. (2007, November 6). Don't look at Drummondville for final word on reasonable accommodation; Bouchard-Taylor open-mike session brings out wide diversity of opinion on immigrants and identity. The Gazette. Montreal, Quebec, Canada. 


\section{"UNVEILING" THE MYTH OF THE MUSLIM WOMAN: A POSTCOLONIAL CRITIQUE}

Heinrich, J. (2007, November 14). 'You'll get the country you deserve'; Lavel appears divided at Bouchard-Taylor commission hearings. The Gazette. Montreal, Quebec, Canada .

Holvino, E. (2008). Intersections: The simultaneity of race, gender and class in organizational studies. Gender, Work and Organization, 15(5), 968-993.

Khiabany, G., \& Williamson, M. (2008). Veiled bodies - naked racism: culture, politics and race in the Sun. Race \& Class , 50 (69).

Lazar, M. (2007). Feminist Critical Discourse Analysis: Articulating a Feminist Discourse Praxis. Critical Discourse Studies , 4 (2), 141-164.

Lewis, C. (2011, January 31). Number of Muslims in Canada predicted to triple over next 20 years: study. National Post . Toronto, Ontario, Canada.

Lewis, T. \& Macmaster, N. (1998). Orientalism: from unveiling to hyperveiling. Journal of European Studies. 28(1-2), 121-135.

Mackie, R. (1994, December 12). Muslim headgear polarizes Quebec. The Globe and Mail. Toronto, Ontario, Canada.

Martin, D. (2007, February 2). Canada comes first. The old country comes second. National Post . Toronto, Ontario, Canada.

McAndrew, M. (2010). The Muslim Community and Education in Quebec: Controvercies and Mutual Adaptation. International Migration \& Immigration, 11(1), 41-58.

Mohanty, C. (1998). Under Wester Eyes: Feminist Scholarship and Colonial Discources. Feminist Review, 30, 65-88.

Norris, A. (1994, November 24). Lemieux blasted for remarks attacking hijabs; St. Jean Baptiste Society head's' not compatible' comment agners Muslims. The Gazette, A3. Montreal, Quebec, Canada.

Nasrulla, A. (1994, December 13). Educators outside Quebec mystified by hijab ban Events in France suggested as link to school's actions. The Globe and Mail, A1. Toronto, Ontario, Canada.

Patriquin, M., \& Gillis, C. (2010, April 12). About Face. MacLean's Magazine, p. 20.

Payton, L. (2010, July 28). QMI Poll: Canadians back burka ban. Retrieved November 11, 2010, from Canoe.ca: http://cnews.canoe.ca/CNEWS/Canada/2010/07/28/14850236.html

Phillips, N., \& Hardy, C. (2002). Discourse Analysis: Investigating Processesof Social Construction (Vol. 50). Thousand Oaks, CA: Sage.

Porter, J. (1975). Ethnic Pluralism in Canadian Perspective. In N. Glazer, D. P. Moynihan \& C. S. Schelling (Eds.), Ethnicity; theory and experience (pp. 267-304). Cambridge, MA: Harvard University Press.

Prasad, A. (1997). The Colonizing Consciousness and Representations of the Other: A Postcolonial Critique of the Discourse of Oil. In P. Prasad, A. J. Mills, M. Elmes, \& A. Prasad, Managing the 


\section{"UNVEILING" THE MYTH OF THE MUSLIM WOMAN: A POSTCOLONIAL CRITIQUE}

Organizational Melting Pot: Delimmas of Workplace Diversity (pp. 285-311). Thousand Oaks: Sage Publications Inc.

Prasad, A. (2003). The Gaze of the Other: Postcolonial theory and organizational analysis. In A. Prasad (Ed.), Postcolonial theory and organizational analysis (pp. 3-43). New York: Palgrave Macmillan/St Martin's Press.

Prasad, A. (2006). The Jewel in the Crown: Postcolonial theory and Workplace Diversity. In A. M. Konrad, P. Prasad, \& J. K. Pringle (Eds.), Handbook of Workplace Diversity (pp. 121-144). London, UK: SAGE Publications Ltd.

Prasad, A., \& Prasad, P. (2002). Otherness at large: Identity and difference in the new globalized organizational landscape. In I. Aaltio-Marjosola, \& A. J. Mills (Eds.), Gender, Identity and the Culture of Organizations. London: Rutledge.

Prasad, P. (2005). Crafting Qualitative Research: Working in Postpositivist Traditions. Armonk, NY: ME Sharpe.

Prasad, P., \& Mills, A. J. (1997). From Showcase to Shadow: Understanding the Dilemmas of Managing Workplace Diversity. In P. Prasad, A. J. Mills, E. Michael, \& A. Prasad (Eds.), Managing the Organizational Melting Pot: Dilemmas of Workplace Diversity. SAGE Publications.

Quebec. (2010). Bill $n^{\circ} 94:$ An Act to establish guidelines governing accommodation requests within the Administration and certain institutions. Retrieved August 5, 2010, from Assemble Nationale Quebec: http://www.assnat.qc.ca/en/travaux-parlementaires/projets-loi/projet-loi-94-39-1.html

Said, E. (1978). Orientalism. New York: Vintage Books.

Sankey, M. (2011, Winter). Cover Up: Why banning the Niqab is Not the Answer. Horizons , 32-35.

Schumann, C. (2007). A Muslim 'Dispora' in the United States? The Muslim world , 97(1), 11-32.

Scott, M. (2010, March 3). Niqab interferes with language teaching: Quebec; Woman Expelled. National Post. Toronto, Ontario, Canada.

Scott, M. (2010, March 3). Niqab heats up rights controversy; Row over veil; Woman refused to uncover face in French class. The Gazette. Montreal, Quebec, Canada.

Scott, M. (2010, April 22). 'The feeling of having been conned'; New study paints an alarming portrait of underemployment among immigrants to Quebec. The Gazette. Montreal, Quebec, Canada.

Spivak, G. (1987). The other worlds: Essays in cultural politics. New York: Methuen.

Syed, J. (2007). 'The other woman' and the question of equal opportunity in Australian organizations. International Journal of Human Resource Management , 18 (11), 1954-1978.

Syed, J. \& Murray, P. (2009). Combating the English language deficit: the labour market experiences of migrant women in Australia. Human Resources Management Journal , 19 (4), 413-432. 


\section{"UNVEILING" THE MYTH OF THE MUSLIM WOMAN: A POSTCOLONIAL CRITIQUE}

Syed, J., \& Pio, E. (2010). Veiled Diversity? Workplace experiences of Muslim women in Australia. Asia i Pacific Journal of Management , 27, 115-137.

Syed, J. (2010). An historial perspective on Islamic modesty and its implications for female employment. Equality, Diversity and Inclusion: An International Journal , 29 (2), 150-166.

The Canadian Council of Muslim Women. (2010, May 7). BRIEF to the National Assembly of Quebec. Retrieved August 5, 2010, from Canadian Council of Muslim Women:

http://www.ccmw.com/documents/Bill94_Brief\%20from\%20CCMW-May_7_2010-2.pdf

Thompson, E. (2010, September 11). Majority of Canadians say Muslims don't share their values; National poll shows significant regional, language divides. The Ottawa Citizen .

Van Dijk, T. A. (1993). Principles of critical discourse analysis. Discourse \& Society, 249-283.

Wallach Scott, J. (2007). The Politics of the Veil. Princeton, NJ: Princeton University Press.

\footnotetext{
${ }^{\mathrm{i}}$ The St. Jean Baptise Society (SJBS) is an organization established to promote French-Canadian interests within Canada, working to preserve the French language and culture and the Roman Catholic Religion.
} 